\title{
A SUGAR, LAUNDRY DETERGENT, AND SALT METHOD FOR EXTRACTION OF DEOXYRIBONUCLEIC ACID FROM BLOOD
}

\author{
Jiří Drábek, Martin Petřek
}

\begin{abstract}
Department of Immunology, Palacký University and University Hospital, Olomouc, Czech Republic
e-mail:drabekj@fnol.cz
\end{abstract}

Received: September 20, 2002

Key words: technical tip / DNA extraction

We present a method for DNA extraction from peripheral blood using sugar, commercial detergent, and sodium salt. Our method is simple, fast, and inexpensive; its qualitative parameters do not significantly differ from the standard salting-out procedure.

\section{INTRODUCTION}

Many commercial and in-house methods exist for the extraction of mammalian DNA from peripheral blood. However, in our opinion none of the published methods meets the composite criteria for yield, purity, reliability, non-toxicity, speed, and price to be used routinely in a small laboratory. A simple method for DNA extraction from human peripheral blood using sugar, commercial detergent (Persil), and sodium salt is presented that fulfils such criteria.

\section{MATERIALS AND METHODS}

Persil from Henkel was purchased at the local store; other chemicals were from Sigma. Statistical comparisons were made on DNA extracted from peripheral blood drawn from one pig at time of slaughter. Optimized DNA extractions were done on peripheral blood of cadaveric donors.

The procedure comprised the following steps:

(i) Lysis buffer (0.3 M sucrose, $0.01 \mathrm{M}$ TrisCl $\mathrm{pH}$ $7.5,5 \mathrm{mM} \mathrm{MgCl}_{2}^{*} 6 \mathrm{H}_{2} \mathrm{O}, 1 \%$ Triton X100) was added to 5-10 $\mathrm{ml}$ of EDTA-anticoagulated blood into $50 \mathrm{ml}$ tube to reach a final volume of $45 \mathrm{ml}$.

(ii) Tubes were centrifuged immediately for $5 \mathrm{~min}$ at $2700 \mathrm{~g}$. Supernatant was discarded and $1 \mathrm{ml}$ of 10 $\mathrm{mM}$ Tris $\mathrm{pH} 8$ added to the sediment. The sediment was released from the bottom of the tube by swirling and poured quickly into a $2 \mathrm{ml}$ tube. (iii) The sediment was resuspended by vigorous mixing and centrifuged for $1 \mathrm{~min}$ at $675 \mathrm{~g}$. The supernatant was discarded and leukocytes resuspended in $1340 \mathrm{ml}$ of $10 \mathrm{mM}$ TrisCl pH8. Leukocytes were divided into two $2 \mathrm{ml}$ tubes, $660 \mathrm{ml}$ each.

(iv) $660 \mathrm{ml}$ of Persil Green Power (Henkel; $20 \mathrm{mg} / \mathrm{ml}$; stored in frozen aliquots) and a clean glass bead ( $4 \mathrm{~mm}$ diameter) was added to each tube.

(v) Tubes with beads were mixed vigorously to homogenize the contents ( 1 min maximally). $500 \mathrm{ml}$ of $5 \mathrm{M} \mathrm{NaCl}$ was added; tubes were mixed vigorously for $10 \mathrm{~s}$ and centrifuged for $5 \mathrm{~min}$ at $17500 \mathrm{~g}$.

(vi) The supernatant was poured into two new $2 \mathrm{ml}$ tubes and centrifuged for $3 \mathrm{~min}$ at $17500 \mathrm{~g}$. The supernatants were combined into one tube and DNA precipitated by adding $3 \mathrm{ml}$ of $96 \%$ ethanol.

(vii) DNA precipitate was retrieved using a glass pipette with heat-sealed thin end and washed in two $1.5 \mathrm{ml}$ tubes with $0.5 \mathrm{ml}$ of $70 \%$ ethanol each. Ethanol was removed by squeezing onto the walls of the second tube and DNA dissolved in $1 \mathrm{ml}$ of $10 \mathrm{mM}$ TrisCl $\mathrm{pH} 8$.

(viii) DNA was incubated for $5 \mathrm{~min}$ at $70{ }^{\circ} \mathrm{C}$. When DNA remained in bulk, it was resuspended by up- and down- pipetting with a filter-tipped $1 \mathrm{ml}$ pipette.

(ix) For the longer term, DNA was stored at $-20^{\circ} \mathrm{C}$. 


\section{RESULTS AND DISCUSSION}

The standard salting-out procedure of Miller et al. ${ }^{1}$ consists of buffy coat separation, overnight cell lysis by serine protease from Tritirachium album (proteinase $\mathrm{K}$ ), salting out by $\mathrm{NaCl}$, DNA precipitation by ethanol, and resuspension. In order to accelerate and economize the standard method, we used red cell lysis ${ }^{2,3}$ instead of buffy coat separation, and replaced proteinase $\mathrm{K}$ with the detergent Persil. ${ }^{4}$ There were no significant differences between the standard method and ours in terms of DNA yield and purity: we measured yield per ml of porcine blood (standard, 47.0 $\pm 7.3 \mu \mathrm{g}$; our method, $40.9 \pm 4.3 \mu \mathrm{g})$ and purity by $\mathrm{OD}_{260 / 280}$ ratio $(1.844 \pm 0.016$; $1.841 \pm 0.012)$. DNA was not degraded and it did not inhibit PCR with sequence specific primers ${ }^{5,6}$ or digestions by restrictases. During five years of use for urgent medical samples, our method has had less than $2 \%$ failure rate and cost $\sim 0.5 \$$ per $10 \mathrm{ml}$ blood sample.

Our DNA extraction may be useful in small laboratories with limited budget or as inspiration for teaching science in grammar schools. According to the company information, Persil contains many components: protease, detergent, builder, silicates, soda ash, polymers, perborate, tetra-acetyl ethylene diamine, optical brightener, dye, sulphate, and perfume. We have not tested what is the exact cause of the equslization proteinase $\mathrm{K}$ and Persil. It can be hypothesised that the makers of Persil engineered their protease and optimalized the whole mixture for release of (in)organic substances (DNA included) from clothes and the high quality of released DNA is incidental. Further, other experiments ${ }^{7,8}$ imply that other laundry detergents than Persil may be used as well.

\section{ACKNOWLEDGMENTS}

This work was supported in part by Czech governmental grants 151100002 and IGA NE/6197. The authors thank Prof. J. T. Epplen for a critical reading of the manuscript, Dr. M. Raška for the gift of restrictases, and $K$. Vránová, and M. Lukešová for technical assistance.

\section{REFERENCES}

1. Miller SA, Dykes DD, Polesky HF (1988) A simple salting out procedure for extracting DNA from human nucleated cells. Nucleic Acids Res. 16, 1215.

2. Johns MB Jr, Paulus-Thomas JE (1989) Purification of human genomic DNA from whole blood using sodium perchlorate in place of phenol. Anal. Biochem. 180, 276-278.

3. Grimberg J, Nawoschik S, Belluscio L, McKee R, Turck A, Eisenberg A (1989) A simple and efficient non-organic procedure for the isolation of genomic DNA from blood. Nucleic Acids Res. 17, 8390 .

4. Bahl A, Pfenninger M (1996) A rapid method of DNA isolation using laundry detergent. Nucleic Acids Res. 24, 1587-1588.

5. Bunce M, O’Neill CM, Barnardo MC, Krausa P, Browning MJ, Morris PJ, Welsh KI (1995) Phototyping: comprehensive DNA typing for HLA-A, B, C, DRB1, DRB3, DRB4, DRB5 \& DQB1 by PCR with 144 primer mixes utilizing sequence-specific primers (PCR-SSP). Tissue Antigens 46, 355-367.

6. Drabek J, Petrek M (1998) 32 bp deletion in CCR-5 gene and human immunodeficiency virus epidemic in the Czech Republic. Acta Virol. 42, 121-122.

7. Pusch C (1997) A simple and fast procedure for high quality DNA isolation from gels using laundry detergent and inverted columns. Electrophoresis 18, 1103-1104.

8. [Online] http://gslc.genetics.utah.edu/basic/wheatgerm/index.html, $13^{\text {th }}$ June 2002 , the last date accessed 
Standard proteinase K method

Our method
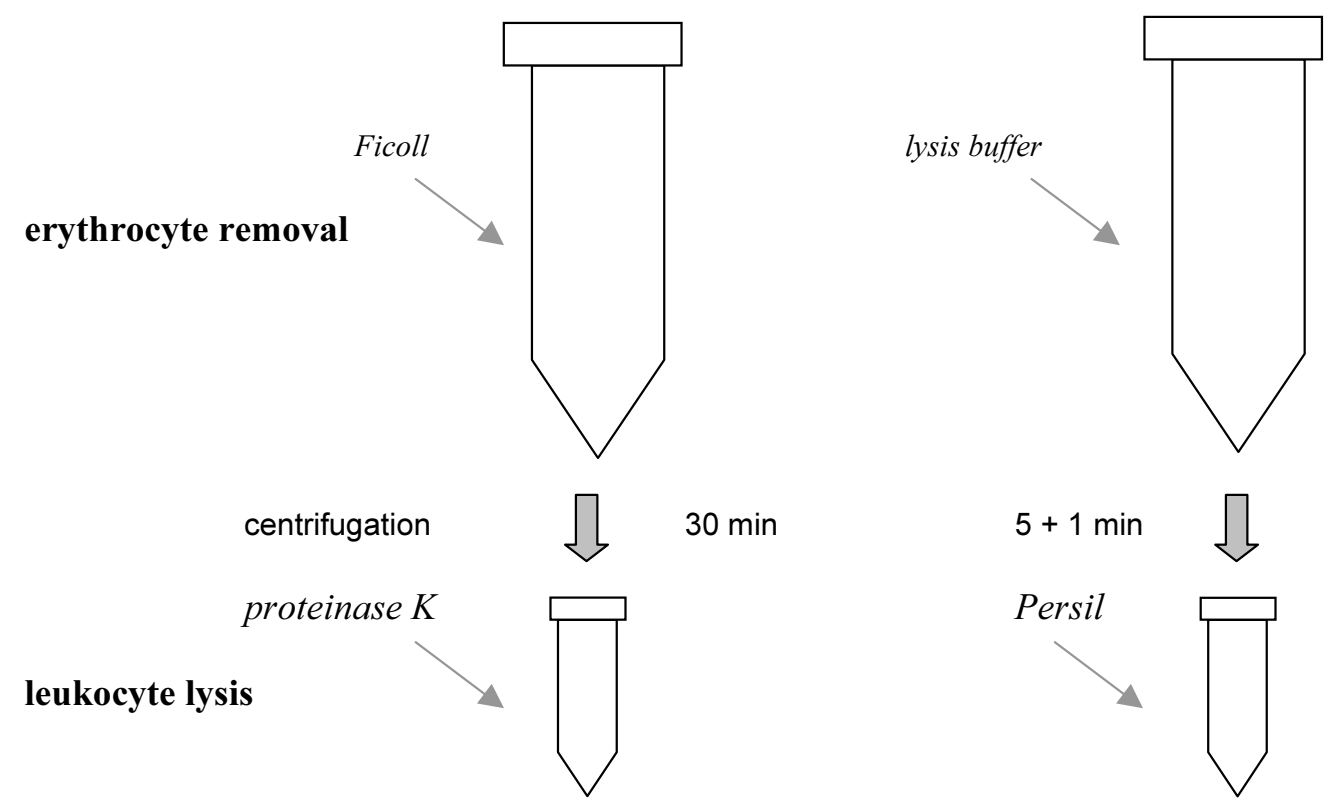

incubation

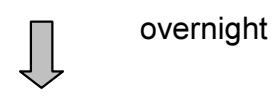

$1 \min$

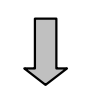

salt

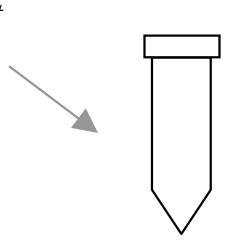

salt

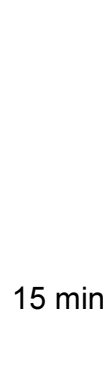

ethanol
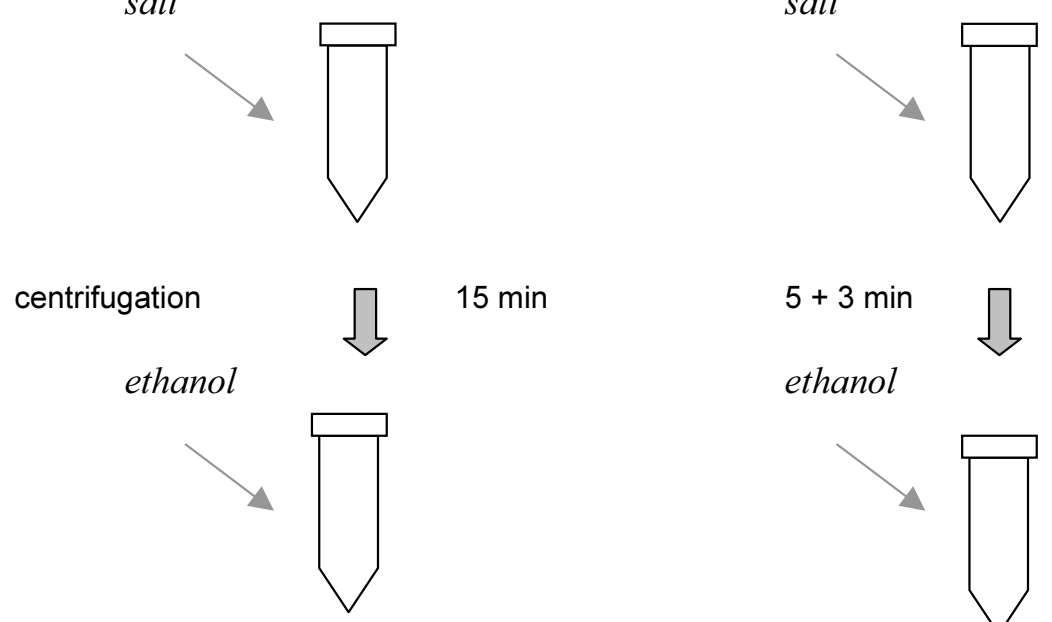

$5+3 \min$

ethanol

precipitation and dissolving

Schema 1. Comparison of standard proteinase K salting-out method with our method 